Discourse and Communication for Sustainable Education, vol. 10, no. 1, pp. 91-112, 2019

\title{
Sustainable Education on the Example of Establishment of Czech Primary Minority Schools in Interwar Czechoslovakia
}

\author{
Michal Šimáně \\ Mendel University in Brno, Brno, Czech Republic
}

\begin{abstract}
The topic of this study is the issue of Czech primary minority schools (ISCED 1) in the period of interwar Czechoslovakia. The specific objective is to describe the development of these type of schools as an example of the sustainability process of Czech education and erudition in general in the border areas of the interwar Czechoslovak state; in other words in the areas, which were inhabited predominantly by the German-speaking population. The research is based on the study of archival sources kept mainly in the Archive of the City of Ústí nad Labem and National Archives in Prague as well as on the study of contemporary legislation. The study brings, among other things, a unique view on the process of disseminating and maintaining Czech education through establishing Czech minority schools in the linguistically heterogeneous areas of the Czechoslovak state. It also indicates the importance of this process in the context of the development of Czechoslovak education system after the year 1945.
\end{abstract}

Keywords: Czech primary minority schools, sustainable education, interwar Czechoslovakia, historical-pedagogical research.

\section{Introduction}

Sustainability of education is currently considered a key factor in the development of the education system. Through the system of pre-school, primary, secondary and other educational institutions, not only the values of education or awareness of environmental change are passed on, but pupils also learn about social and cultural values for lifelong learning. In general, these institutions influence the development of their personalities so that they acquire the expected knowledge and skills necessary for functioning in responsible citizenship and active life (Guseva et al., 2007; Andersone in Badjanova \& Iliško, 2015; Iliško, 2007).

In this context, however, a question arises. Iliško et al. (2017) suggests that the very definition of sustainable of education can be interpreted differently and also challenged. It is therefore important, as Salite et al. (2016) point out, to approach the sustainability of education transdisciplinarily. To try to constantly explore the nature of the complex phenomenon not only in one area, but also to search for essential relation- 
ships or attributes that appear to be sustainable or unsustainable in other areas must aim to positively influence the further development of education, society knowledge and science.

Although the author (Salite et al., 2016) does not explicitly name specific areas that should be studied in the context of sustainable education, an appropriate one may be history, i.e.: the History of Education. The History of Education has been so far neglected in this context. Nevertheless, the historical (historical-pedagogical) view may provide unique knowledge and inspire and deepen a professional discussion on the sustainability of education in today's world.

For example, the mother tongue in which the education and training take place can be considered one of the key features of education sustainability. The availability of education in the mother tongue, and the dissemination and maintenance of national knowledge within a single state today, may seem to be a matter few people would think about. In the past, however, this was a very sensitive issue that caused many conflicts especially in states that were made up of many ethnic varieties where only one held a dominant position and others had to adapt. In this context, we can talk about the Austro-Hungarian monarchy or the Russian empire of the $19^{\text {th }}$ century. This problem, however, is not only typical for the $19^{\text {th }}$ century and has resonated in some countries even recently. An example may be the dissolution of the Soviet Union after 1990, and the related end of efforts regarding the nations that were part of the USSR (for example, the Baltic republics, see Rahi-Tamm \& Saleniece, 2016, Iliško, 2007). Examples can as well be found between the world wars. One of them is the Czechoslovak Republic, which was constituted as one of the successive and at the same time multiethnic states after the collapse of the Austro-Hungarian Empire in 1918.

It is the period of existence of the first Czechoslovak Republic that is the issue of this study. In particular, it is the question of establishing Czech primary minority schools, which represented the "islands" of the Czech element in areas speaking the foreign language. At that time, it was a very specific type of school, whose name was not even embedded in historical legislative documents. It is revealed, however, by the material from the meeting of the Czechoslovak Ministry of Education and National Enlightenment (MENE). From the material, a certain degree of helplessness among the officials is visible. ${ }^{1}$ They have eventually stated that "a more detailed interpretation of the term minority school will not be given, and that determining which school is minority and which not will be left to decide on a case-by-case basis" (Pojem "menšinová" škola, p. 13).

Due to the ambiguity in the terminology used, the term minority school was from the time of Austria-Hungary used in practice and in journalism for schools founded in areas where the majority population spoke a different language from the one used for teaching at that school (Měchýř, 1996; Trapl, 2003). This was true not only for Czech schools established mainly in the Czechoslovak border areas ${ }^{2}$ but also for German schools in upcountry Czech regions.

The Czech primary minority schools can be, in this case, an example of the effort to disseminate Czech education within the Austro-Hungarian Empire and during the first Czechoslovak Republic, as well as an example of efforts to sustain the Czech education and knowledge in the border areas of the present Czech Republic not only during the mentioned periods, but also in the years after 1945 . 


\section{Methodology}

The objective of this study is to describe the Czech primary minority education as an example of the process of sustainability of Czech education and Czech knowledge in general in the border areas of the Czechoslovak state, which were inhabited predominantly by the German-speaking population during the interwar period of Czechoslovakia. Therefore, the main research question of this study focuses on the way in which Czech primary minority schools were established in the Czechoslovak border areas, thus pointing to the process of dissemination and maintenance of Czech education in these regions. With regard to the scope of the study and the research realization ${ }^{3}$, it has be geographically narrowed down to the exploration of this issue in the political district of Ústí nad Labem ${ }^{4}$, which was in the period of the first Czechoslovak Republic one of the important Czech-German linguistically mixed regions. ${ }^{5}$

Fundamental for the research part of this study was the acquisition of relevant resources from that time that would allow learning about the circumstances of the establishment of Czech primary minority schools. These were archival materials obtained by studying especially in the Archive of the City of Ústí nad Labem (AcUL) and the National Archives in Prague. From archival sources, all available materials related to the subject matter kept in AcUL were used. In particular, it was the archival fund of the District School Inspectorate in Ústí nad Labem, which contains the specific registries of individual schools in the district. In this context data was collected also from the funds of individual Czech primary minority schools and some German primary schools in Ústí nad Labem and its surroundings. These include: school chronicles, memorial books, records from conferences, school committees, class catalogues and more. Similarly, some information was obtained from the Ministry of Education fund in the National Archives in Prague. Apart from the archival materials, the contribution is based on the study of several contemporary legislative standards and other materials.

When studying archival materials traditional methods of historical research were used. In this context mainly direct and indirect methods and historical-comparative methods were employed (see Zounek \& Šimáně, 2014).

\section{Historical Context}

The results of the First World War represented a crucial event for the peoples who were part of the former Austro-Hungarian Empire. The inhabitants of this former empire, on the basis of the right to self-determination of nations, could establish their own states. One of the successor states of the disintegrated Austrian monarchy was the Czechoslovak Republic formed by the merger of the three historical parts of the Czech state (the Czech Kingdom, the Margraviate of Moravia and the Duchy of Silesia) with the newly constituted Slovakia and the newly founded Carpathian Ruthenia (Kárník, 2002). The creation of independent Czechoslovakia meant a fundamental historical transformation that brought new challenges for this State in the field of its construction, spiritual creation and defence. At the beginning of its existence, Czechoslovakia "inherited" both the old values of Austria-Hungary and the new ideas that originated mainly in foreign and domestic resistance movements. One of these new ideas was also reflected in the fact that the Czechoslovak Republic was established as a parliamentary democracy based on general electoral law and pluralism of political parties (Kořalka, 1998). The program of the new republic was outlined by president T. G. Masaryk, whose program efforts 
can be described as de-Austrification. Masaryk understood it as the need to get rid of all the old elements built up by the former undemocratic system of Austria-Hungary. "A free citizen, self-confident, aware of his democratic rights and duties" should have become the new ideal (Hanzal, 1999, p. 148).

The emergence of a new state was accompanied by a number of problems. Together with the "transcription" of the borders of the former monarchy, many ties were broken, not only in the political but also in the social or economic spheres. The solution to these problems, along with global events, influenced the development of Czechoslovak society in the next two decades, including education.

In these efforts, the new state had to deal with many issues inherited from the former Austro-Hungarian Empire, or, as Valenta (1999) wrote, received as a dowry from the Austro-Hungarian monarchy. Many problems arose from the interconnection of the former parts of Austria-Hungary, because differences in the ethnic composition of the population and their socio-economic status, ideological contradictions, international political influences or different political traditions between different parts of the state, began to reflect in the new state (Harna, 1990). This situation concerned most of the new States emerging from the ruins of the multiethnic monarchy. This was due to the fact that the victorious powers supported the emergence of these new States primarily with regard to their own strategic, economic and transport interests (Ferenčuhová, 2006; Kořalka, 1998).

An important question in connection with the topic of this study is the ethnic question. Czechoslovakia, which was founded based on historical Czech lands and a merger with the territory of Slovakia and Carpathian Ruthenia, was not an ethnically homogeneous state. It had to face fundamental decisions at the very beginning of its existence. The fear of Germanism ${ }^{6}$, along with the euphoria of victory and the establishment of the republic, together with the political actions of minority representatives in the early days of the new State's existence and other circumstances led to the adoption of the concept of the Czechoslovak state ethnicity, where the main role during the building of Czechoslovakia should have been played by the Czechs and Slovaks (Kural, 1993; Lemberg, 1993). Other ethnic groups living within the Czechoslovak Republic had to reconcile with the minority status?

Even the German ethnic group was, after the Czechs, the second most populous ethnic group in the territory of the First Republic (see Table 1). The decision of the Czechoslovak government was therefore hard to accept for the German population. This was also due to their former majority position within Austria-Hungary. It is not surprising that, in particular, the Germans (but also the Hungarians) perceived this situation as another act of the ethnical dictatorship of the Czechs and Slovaks (see Wils, 1993, Bakke, 2004, Kárník, 1999).

During the twenty years of existence of the First Republic, many stages between collaborative and separatist efforts by other ethnic groups can be observed. Even before the establishment of the Czechoslovak Republic, we can notice the activities of German nationalists, whose aim was the organization of their own self-government and the military security of the border areas in Bohemia. As a result, the Czechoslovak border regions, considered as closed German territories, would have been separated (Matějček, 2003). These tendencies followed the pursuit of the aims of the German political circles in the First World War and the Greater Germanic concept of a new arrangement of relations in Central Europe. The great support for these tendencies represented the announcement of so-called German-Austria (Deutsch-Österreich) at the meeting of the 
Austrian Provisional National Assembly on October 21, 1918, which had to determine the further direction of the German territories of the dissolving Austria-Hungary (Schelle, 2006, Lemberg, 2007).

Table 1

Nationality Composition of the Population in the Czechoslovak Republic in 1921 (based on data from Tóth, Novotný \& Stehlík, 2012; Kořalka 1998)

\begin{tabular}{lcc}
\hline \multirow{2}{*}{ Ethnic } & \multicolumn{2}{c}{ Year 1921 } \\
\cline { 2 - 3 } & Population & Percentage representation \\
\hline Czechs & 7406493 & $52 \%$ \\
\hline Germans & 3123568 & $22 \%$ \\
\hline Slovaks & 2282277 & $16 \%$ \\
\hline Hungarians & 745431 & $5 \%$ \\
\hline Ruthenians and Russians & 461849 & $3 \%$ \\
\hline Jews & 180855 & $0.5 \%$ \\
\hline Poles & 75853 & $0.3 \%$ \\
\hline others & 25871 & $100 \%$ \\
\hline Total & 14226344 &
\end{tabular}

The German regions in the Czech lands, including the individual language islands ${ }^{8}$ (see Map 1), should therefore have joined German-Austria in accordance with the principle of self-determination of nations.

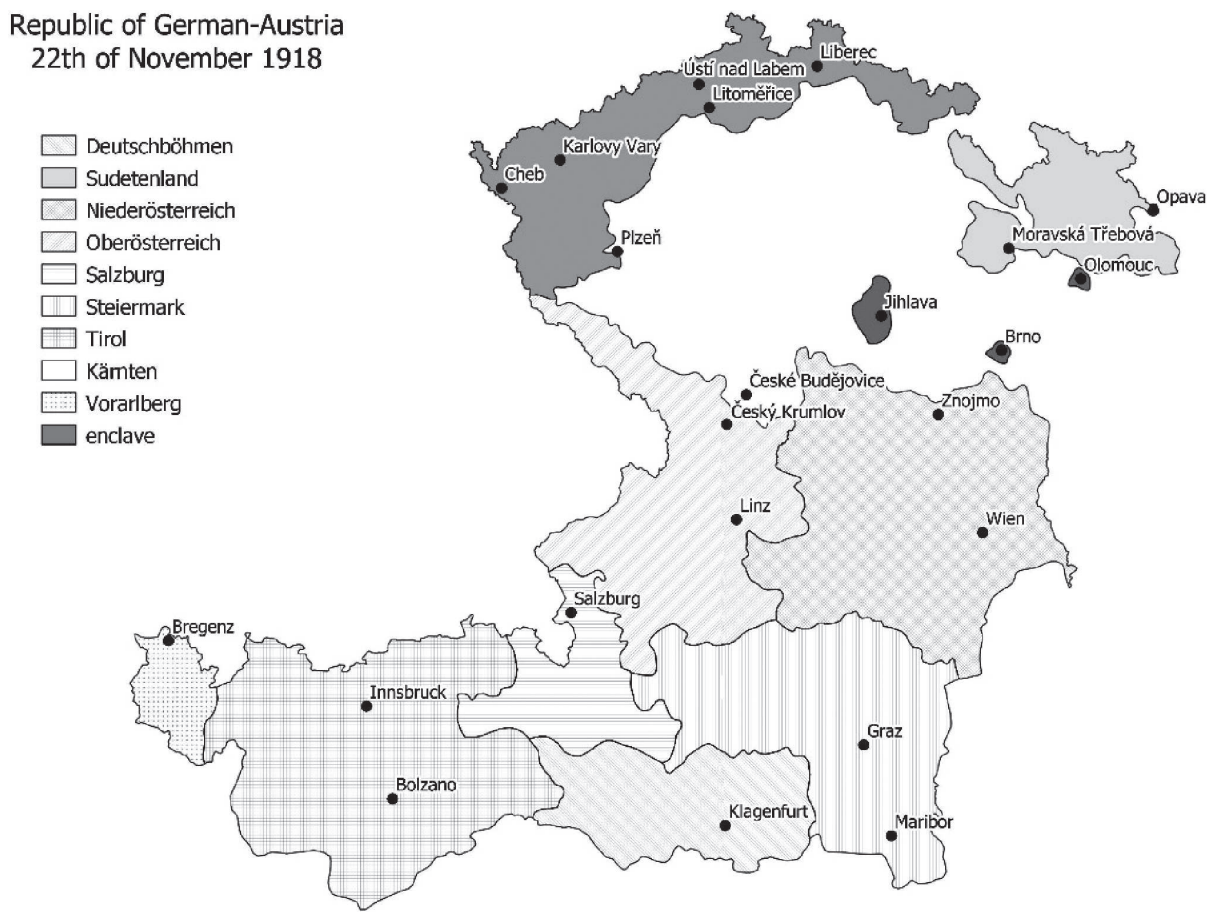

Map 1. German Austria on November 22, 1918 (created by the author based on the study of literature and sources) 
However, as Peroutka (1991) notes, Austrian and Sudeten Germans ${ }^{9}$ have somehow forgotten in their call for the principle of self-determination that they were still in a state of war with the author of this idea, the US President Woodrow Wilson. Moreover, the realization of the Austrian and Sudeten German's ideas on the merger of Austrian Germany with the German regions in the Czech lands, and the subsequent incarnation of this constitution into the German Empire (within the so-called idea of greater Germany), would basically mean a significant strengthening of Germany (see Valenta, 1998, Hoensch, 1969). With this or similar result of the war, however, the victorious powers would never have agreed.

However, the goal of Czechoslovak politics was not to discriminate Sudeten Germans in any area of their lives. The problem was that the German population was unwilling to accept the status of an ethnic minority, and the Czechoslovak government did not want to give up on its vision of the Czechoslovak ethnicity as a leading element of the Czechoslovak State. Basically, it was a conflict of principles affecting both ethnic groups' relations throughout the existence of first Czechoslovak Republic.

The stabilization of the relations in the 1920s led to a gradual straightening of Czech-German relations, manifested by the involvement of important German personalities from political, economic and cultural spheres in the construction of the Czechoslovak state (Pernes, 2005). The concrete expression of German activism in the policy of the Czechoslovak State was then the cooperation of some German parties in the parliament (Brügel, 2006; Kárník, 2003; Broklová, 1993).

The turn of the 1920s and 1930s is marked by the return of German politics to the negative tendencies towards the Czechoslovak State similar to those of 1919 and 1920. There were several reasons for that. The first was a major economic crisis that began with a collapse on the New York Stock Exchange in October 1929. The second was Hitler's rise to power in Germany in the spring of 1933. The Great Depression was a worldwide disaster that affected Czechoslovakia twofold in the context of Czech-German relations. The crisis affected the border regions the most. Of the 500,000 unemployed in Czechoslovakia in 1932, there were 400,000 in the Sudeten German region (Glassl, 1995). At the time when the economic crisis culminated in Czechoslovakia ${ }^{10}$, Adolf Hitler also rose to power in Germany. During his speech at the Reichstag on March 23, 1933 - on the day he received unlimited power as the Enabling Act passed in Germany among other things, he said that in the future, Germany would commit to special responsibility for the fate of Germans living abroad (Jaworski, 1991). For the first time, a still unspecified threat, which also involved the Czechoslovak State, appeared. The failure of the Czechoslovak government to solve the economic crisis in the border areas and the consequences of the national policy of the Czechoslovak State, according to Loužil (1995), led to a shift in the perception of the national identity of the Sudeten Germans to a Greater German national identity.

In the following years, the dissent between the Czech and German populations was only deepening, as a result of the annexation of Austria by Hitler's Germany, which Western democratic powers accepted without major protests (Drtina, 1991). The Henlein's ${ }^{11}$ Carlsbad program ${ }^{12}$ announcement in April 1938 basically marked the end of the first Czechoslovak Republic, which came at the end of September in connection with the forced adoption of the Munich Agreement. 


\section{Establishment of Czech Primary Minority Schools on the Example of the Political District of Ústí nad Labem}

The issue of minority schools at the time of the first Czechoslovak Republic is closely related to the general development of education in this period. Minority schools had the same position in the school system as any other Czechoslovak school institution. Many laws and regulations that set out the rules for the functioning of "non-minority" schools also applied to this specific type of educational facilities, whose tradition dates back to the Austro-Hungarian Empire. These were schools that operated in the linguistically mixed areas of the Austro-Hungarian monarchy. In the Czech lands territory, these were mainly the current border areas, where mainly the German population lived during the Austro-Hungarian Empire and the First Republic. While in the period before 1918 the Czech requirements for the establishment of Czech schools in these areas were marginalized by the Austrian authorities, the establishment of the Czechoslovak Republic represented a new hope for many Czech inhabitants living in the border areas for a change of the current state, but at the same time brought new problems.

\section{Austro-Hungarian Prelude}

Czech minority schools operated in accordance with the Hasner Act and its amendment from the Austro-Hungarian period (Číslo 62, 1869, Číslo 53, 1883). Although this act enabled the development of Czech education in linguistically homogeneous regions, wording of this act was very indefinite concerning minority education. The establishment of minority schools depended on the fulfilment of many criteria and the school authorities as well as the municipal administration took part in the decisionmaking process concerning setting up a minority school. The latter one could have exerted pressure, and it did, in various forms on the Czech population to waive their request for a minority school establishment (Měchýr̆, 1996).

The establishment of minority schools became a real struggle in the second half of the $19^{\text {th }}$ century. It was the struggle between the Czech population and the Austrian authorities, which were mostly in the hands of the German population in the border areas. In these situations, the Czechs used the possibility of setting up a private school. Hasner Act allowed it. Private schools, however, had to be managed entirely at the expense of its statutory authority. The state did not fund them (Č́slo 62, 1869).

Even the establishment of a private school did not necessarily lead to its final opening for Czech pupils. The statutory authorities had to comply with the other points of the Hasner Act, which led to often irresolvable situations for the Czech population (see Šimáně, 2010). This state remained unchanged until the end of the First World War.

Efforts to establish Czech schools in the political district of Ústí nad Labem can be observed in connection with the growing number of Czech immigrants to northern Bohemia as early as in the second half of the $19^{\text {th }}$ century. However, the first groups of the Czech inhabitants did not think about educating their children. The reason was the fact that incoming workers and miners often could not have afforded to let the children spend their time at school "when every hand was needed at home" (Měchýr. 1998, p. 112). The change took place with the incoming Czech teachers and editors to the border areas who were the main initiators of activities for the minority. 
The very first Czech primary minority schools were founded in northern Bohemia during the Austro-Hungarian period, with the significant contribution of the patriotic engineer and teacher Jan Bydžovský. Due to his efforts, schools were established in 1882 in Duchcov, in 1883 in Most, in 1886 in Bílina and other municipalities (Šafránek, 1918).

Similar efforts were made to establish a Czech primary minority school in the district of Ústí nad Labem. The first attempts were made directly in the town of Ústí nad Labem relatively shortly after the Hasner Act was issued. It happened during the term of a patriotic member of the Czech nobility and the district governor Count Jindrich Kolovrat, who was in the office from 1872-1878 (Staněk, 1909).

The Czech primary school in the village of Krásné Březno became the first successfully established Czech school in the political district of Ústí nad Labem in 1896 (Školy různé záležitosti, kart. 150, undated). The opening of this school was of great significance also for the Czech minorities in surrounding municipalities. In those, the attempts to establish a Czech school were not successful, so the children from these villages attended school in Krásné Březno. Similarly, a school in the village of Chabařovice (Školní kronika 1919-1939, undated) was established in the Austro-Hungarian period. Until the First Republic was founded, no other Czech schools were established in the Ústí nad Labem district (see Map 2).
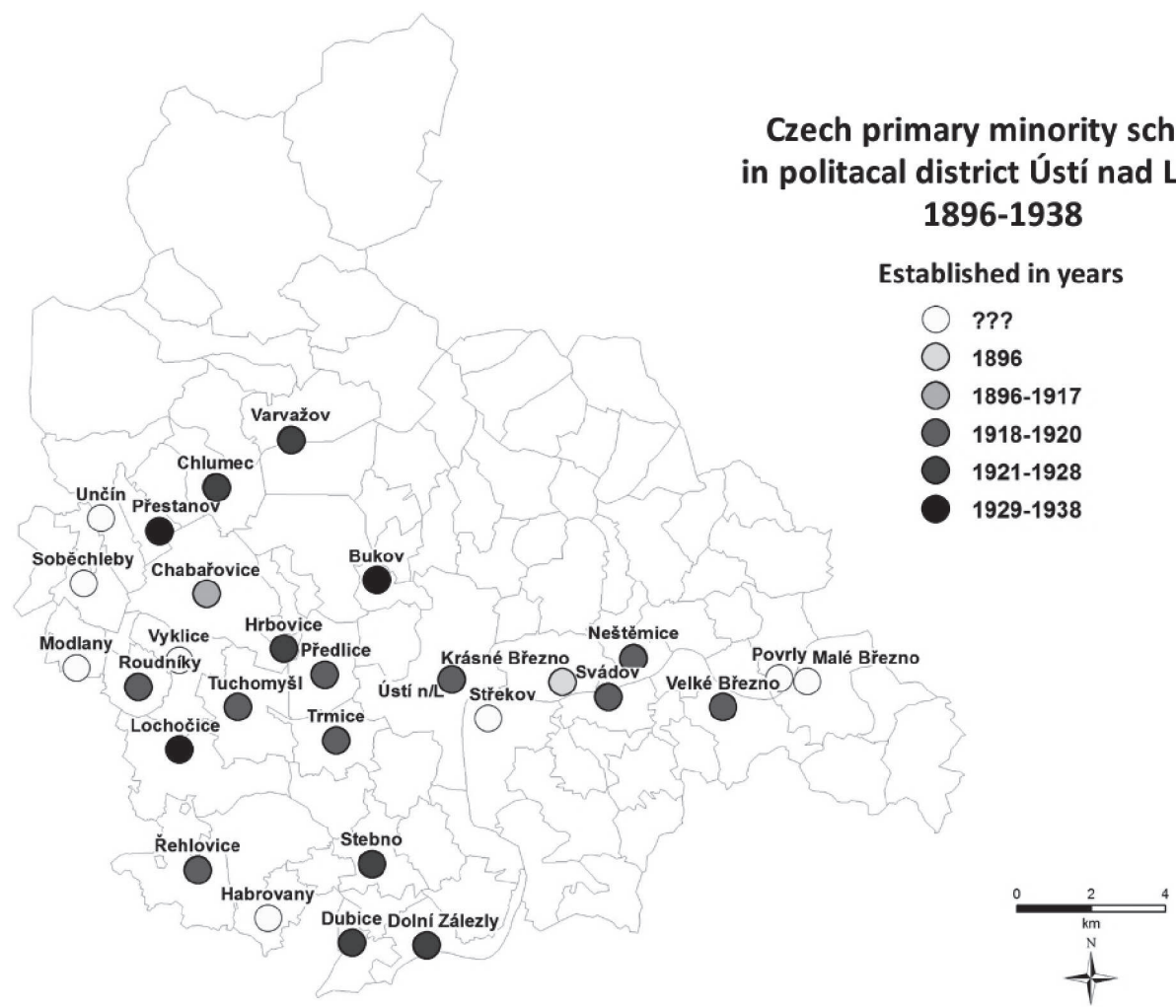

Map 2. Czech minority schools in the political district Ústí nad Labem in the years 1896-1938 (created by the author based on the study of literature and sources) 


\section{The Czechoslovak Part}

Under the new circumstances of the Czechoslovak state, the issue of minority education was addressed by the Metelka Act (Číslo 189, 1919). The Act amended the unclear provisions of the Hasner Act and its amendments related to the establishment of primary and lower secondary schools. At first, the minority education started to fall directly under the highest school authorities, namely the territorial school council, respectively MENE. Municipalities, perceived as the main source of obstructions under the former regime, became completely excluded from the process of the establishment of the minority schools. In addition, schools could, under certain conditions, have been newly established for any number of school children.

The establishment of Czechoslovak Republic was accompanied by expectations for improvement of the situation regarding the establishment of Czech primary minority schools. This is evident in one part of a speech given by Josef Hořčice, who, after the arrival of Czechoslovak troops at Ústí nad Labem in December 1918, became one of three Czech members of the newly elected twelve-member city council. In front of the crowds of Czechs who, on the occasion of the elections, were present in front of the town hall, he uttered among other things the following words: "Our first and most sacred duty will be to establish schools in Ústí nad Labem in a number and kind that corresponds to the needs of the Czech people" (Kaiser, 1995, p. 161). From this moment on, the Czech minority for the first time in history had the support in the city council for the establishment of Czech schools.

In many border regions, the first months of existence of the Czechoslovak Republic were also accompanied by the emergence of new Czech schools. These, however, were set up completely spontaneously, without any legislative background, due to the general euphoria stemming from the acquired freedom. The relevant law was issued in April 1919 (Valenta, 1995). The establishment of schools, which until April 1919 had no legal background, did not represent the main problem for Czech schools. The main issue was the practical level of their functioning, the actual realization of the teaching process, which had to comply to the letter of the law (Číslo, 189, 1919; Číslo, 295, 1920). Simply put, in many cases, after their establishment Czech schools did not have any room available where the classes could have taken place.

The newly issued Metelka Act reacted to the situation of the uncontrolled growth of the number of Czech schools in the border areas with some of its provisions. In addition to the rules for the establishment and opening of primary and lower-secondary schools, it also determined the conditions for their placement. A significant provision in this respect was the possibility of renting or even expropriating entire buildings or rooms from other entities. One of the paragraphs literally stated that "every landlord is obliged to rent his room for these purposes (teaching) if it does not endanger his own living or trade... or to expropriate the already built building so that the school and a custodian's apartment can be located there" (Č́slo, 189, 1919, p. 264). With this paragraph, the Act to a certain extent reacted to the very complicated conditions in which the new state found itself. These conditions included general economic disintegration, transfer of industry from the war mode of operation, high unemployment rates, housing crisis and more. As a result, the first steps of the new government in the current situation led to the search for methods and means to weaken the causes of this social tension (Deyl, 1990). There was just no space for the construction of new school buildings in this period. 
Nevertheless, by issuing this Act, the problem of finding room for the newlyestablished schools did not disappear. Many of the sources stored in the Archive of the City of Ústí nad Labem in the funds of the individual Czech and German primary schools in Ústí nad Labem reveal several typical situations that occurred when attempting to open a Czech school. ${ }^{13}$ First of all, some of the schools were located in the buildings of German schools. Further, there were schools that were not located after their establishment and de facto not even opened for many years. In addition, there existed schools located in areas that were far from the conditions required by law. Moreover, some schools were located in places that did not comply with the conditions required by law. Last but not least there existed also schools that acquired their own buildings for themselves.

\section{A Disrespectful Guest}

The Metelka Act, in addition to the provisions that premises could be rented or expropriated for teaching, also set the precise rules of negotiation in these processes. These negotiations, or so-called commission proceedings, took place with the participation of the owner of the real estate or his representative and the persons appointed by the chairman of the territorial school council, or in the case of schools established by the Ministry of Education and National Enlightenment, by a person authorized by the Ministry itself. The purpose of these meetings was to determine the condition of the rooms or buildings for possible renting or expropriation. The commission proceedings were conducted based on a request made to the abovementioned institutions - to the territorial school council or MENE. Consequently, the requested rooms were examined with the participation of all accredited persons and evaluated. (compare Ćíslo 189, 1919; Č́slo 295, 1920; Školy - různé záležitosti, kart. 150, undated).

These commission proceedings were often directed to already existing German school buildings, or to school buildings where a German (primary or lower-secondary) school functioned. These measures were not aimed against the German population and its culture, as it was often understood by the German citizens, especially after the publication of the Metelka Act (see Umlauf, 1960), but for purely practical reasons. Before 1918, children of Czech parents attended German schools. The evidence can be found in various archival materials such as class registres, class catalogues, lists of schoolchildren. ${ }^{14}$ Therefore, the number of children did not increase in any way; they were only divided according to their ethnicity. The same thing happened with the school building.

These acquisitions of a part of a building, even though expected otherwise, proceeded without major ethnic or other confrontations (Goldbach, 1998). This can be illustrated by the following excerpt from the school chronicle of the Czech primary school in Neštěmice:

Due to the urgent need for suitable rooms for the Czech school, Mr Jan Kamenicky, the plenipotentiary of the territorial school council, governor and secretary in Usti nad Labem negotiated the lending of the rooms for the Czech school with the municipality. The negotiations led to the result without any difficulty, and the municipality decided to lend the second floor of the German school building for this purpose, namely four classes and one room for the office (Školní kronika 1919-1933, undated, unpaged).

Conflicts occurred in the years to come with the growth of the number of Czech pupils and the decrease of the German ones. The decrease in German pupils was also 
accompanied by a reduction in the number of German classes. This was enabled by the Metelka Act (Č́́slo 189, 1919). These reductions ended in some cases in the complete closure of German schools, often for economic reasons. These situations the German population perceived as so-called Schuldrosselungen, that is the oppression of German schools or the oppression of German culture (Kořalka, 1997; Umlauf, 1960).

\section{Provisional Arrangement}

However, not even this solution was ideal in terms of teaching. From the school chronicle of the Czech primary school in Neštěmice, we can see that even three schools (the German boys' school, the German girls' school and the co-educational Czech school) operated in the original German school building. Moreover, the gym had to be closed and converted into a flat for the Czech headteacher (Školní kronika 1919-1933). In addition, this daily coexistence was accompanied by many minor skirmishes that resulted, from the day-to-day encounter of pupils of individual schools located in the building (Školní kronika 1921/1935). Interestingly, these conflicts arose only at school. From the conference report of the Czech school in Předlice, it is possible to find out that Czech children were usually friends with German children out of school on all possible occasions. The opposite occurred when the children met at school. "When arriving at school, most of the friendly relations are disappearing, German children very often avoid Czech children, and even they often persecute them. We often have to take action against the invectives of German children at the Czech ones “(Konferenční protokol 1934/1948, unpaged). However, these conflicts did not necessarily result from the national antipathy of pupils or teachers, as stated by both Czech and German teachers, but the characteristics typical of school-age children could be seen in these situations, such as the need to show off, to stand proof in front of others and so on (Helus, 2004).

The ethnic subtext of these minor conflicts is more likely to be perceived from school auxiliaries, such as janitors and cleaners. They usually remained at their positions and were of German origin after the division of the school. According to preserved reports, this staff dealt in a somewhat peculiar way with the new situation: slapping Czech children when they came to school was a "favourite pastime" of the custodian Krausse (Schulchronik 1919-1931).

\section{Endless Search}

Not all the commission proceedings concerning the rental of suitable rooms for teaching were successful. This often concerned municipalities where the condition of the local German school did not allow the provision of the rooms for the Czech school, or where the German school was completely missing and the local children of both Czech and German parents attended schools in some of the neighbouring municipalities. An illustrative example can be the events related to the efforts to open Czech primary minority schools in Chlumec and Lochočice.

Just after the First Republic was established, a commission was set up in Chlumec to manage the work on the establishment of a Czech primary school. The chairmen of this commission were J. Černý, J. Hašek and J. Slavík. These men together made a list of Czech children, which represented a prerequisite for applying for the establishment of a school. As noted in the school chronicle: 
After obtaining the necessary legal number of children, a request was made on 14 May 1920 to Prague for the establishment of the Czech primary public school here. Already on June 1, 1920, by the Decree of the Territorial School Council in Prague from 21 May 1920, No. IV - 5.154 the request was approved and thus according to the Act of 3 April 1919, No. 189 Coll. the State Administrative Committee decided in agreement with the Ministry of Education and National Enlightenment to set up a public elementary school in the village of Chlum with Czech as a teaching language. The school should be opened at the beginning of the school year 1920-21. Now it is necessary, according to $\S 7$, to locate the building in which the school will operate (Školní kronika, 1922-1938, unpaged).

This report demonstrates the course of establishment and opening of a minority school. According to this report, the school was officially established, but it could not really have worked. The reason was the absence of suitable teaching rooms and other material provisions. In these cases, according to the Metelka Act, a commission had to be set up to carry out an investigation into the rental of suitable rooms for teaching. The protocol written on May 20,1920, at Chlumec municipal office shows how such a proceeding was carried out:

Regarding the question of the commission, which spaces the local school council provides for a new Czech school, the mayor of the municipality - as the chairman of the local school council-stated that there is no room for the Czech school in the building of the German school in Chlumec. Apart from the custodian's flat, the school had 7 classes with 376 school children currently attending the school. Even with the decrease in the number of children in each class due to the Czech children leaving, none of the classes would have so few children, to make it possible to merge two classes into one (Školní kronika, 1922-1938, unpaged).

The mayor, therefore, proposed other spaces, that those taking part in the proceeding inspected and which they evaluate in one of the following reports:

The suggested groups of rooms do not meet, as it was already mentioned, the requirements ${ }^{15}$, which are demanded for a classroom, but because, according to the statements of all the participants of the commission, there are no other suitable rooms available, the Czech school could be temporarily located here. The representatives of the Czech parents and the owner of the house, the landlord Westfahlen, agree with the above-described group of rooms (Školy, různé záležitosti, kart. 151, undated, unpaged).

We can learn about the progress in obtaining the rooms in the chronicle of this Czech school. According to the chronicle, Westfahlen's proposal was accepted, and the Czech school would have been located in a former distillery. Afterwards, the most urgent building modifications and getting the basic material supplies for the school followed, including the school desks. In agreement with the local German school council, the German school should have provided them. However, the Czech school emergence in Chlumec caused a wave of protests among the local German population, which manifested itself in the boycott of this school and in "agitational" visits to some not yet decided 
Czech parents. Their aim was, in particular, the enrollment of their children in the German school. The culmination of this boycott was the statement by the German headmaster: "I'd rather break and burn the desks than to provide them for the Czech school" (Školní kronika, 1922-1938, undated, unpaged).

However, the situation in Chlumec eventually calmed down, despite the fact that the desks were not provided. On September 12, 1920, a new Czech primary school was solemnly opened and the day began with the classes. They, however, began in a peculiar situation described in the following citation:

The Czech school lacked everything, it did not have the smallest piece of furniture, no teaching aids, and it did not even have the most important thing, namely the desks. The first day in the Czech school was, therefore, more enjoyable for the children as they were allowed to sit on the floor (Školní kronika, 1922-1938, unpaged).

Since the desks were not delivered on the following days, the classes took place in the countryside. Eventually, everything was saved by the arrival of the district governor of Ústí Jan Kamenický, who solved the situation by buying 53 benches from the German school for 1500 CSK which were immediately transported from the German school to the Czech school (ibid).

\section{In their Own Building}

Some Czech schools in Ústí nad Labem managed to get their own needed rooms for their school immediately after their legislative establishment. The question, however, was the quality of such spaces. The aforementioned Czech school in Chlumec after the meeting with the owner of the local chateau and distillery was provided with a distillery facility (Školní kronika 1922-1938). Although the building was subsequently adapted for school conditions, after several years of teaching in these spaces, the school representatives and pupils' parents experienced, after the first enthusiasm, a certain disillusion: "Due to appearance and inappropriate placement, it does not suit the purposes, neither for teaching nor training," was one of the complaints by the school custodian (ibid, unpaged).

The situation concerning school buildings of Czech schools had generally improved in Ústí nad Labem during the end of the 1920s and the beginning of the 1930s - in other words in the period when the economic boom of the Czechoslovak state culminated (see, for example, Jakubec, 1999).

Based on archival sources and secondary sources, it can be assumed that in Ústí nad Labem new school buildings were selected mainly for larger Czech schools, at least five-class schools involving about 150 or more children, such as Neštěmice, Krásné Březno, Chabařovice and Ústí nad Labem (Školní kronika 1919-1933; Školní kronika 1921/1935; Kronika školní, undated; Kaiser, 1995).

The events of the second half of the 1930s did not provide many opportunities to build new school buildings. The aftermath of the economic crisis, the rise of Hitler's power in Germany, along with the growth of the Konrad Henlein's movement, had directed government policies to address more urgent issues such as the defending against a deliberate effort to liquidate the Czechoslovak Republic as an independent state (Kováč, 1993). There was not much space for addressing school issues. 


\section{Discussion and Conclusion}

At the beginning of this study, the ideas of Salite et al (2016) were introduced, which encourages the scholars to perceive sustainability of education in a transdisciplinary way and seeks relationships or features that seem to be sustainable or unsustainable in other areas and, consequently positively influence the further development of education, knowledge and science. The previous text shows that one area where "relationships" and attributes can be "sought" may be history - in the case of this study - the history of Czech minority schools in the period of the first Czechoslovak Republic. One of these attributes may be the mother tongue in which education and training were carried out at these schools.

In this context, we can then talk about two points of view on the issue of sustainability of education, which may be somewhat inspiring even for further historical or historical-pedagogical research.

In the first place, the Czech Minority Schools can be perceived as attempts by Czechs to promote their language and at the same time education and culture even in the historically Czech regions, where the German population prevailed during the AustroHungarian Empire and the period of the first Czechoslovak Republic. In the AustroHungarian period, attempts to establish a Czech school were suppressed by the Germans. The ruling and dominant ethnicity at that time, with the establishment of the Czechoslovak Republic, meant the "fortune" changed at first sight. The new state represented a new option for the Czechs to get into the border areas as well.

However, research results show that the situation was more difficult than it might seem at first sight. These schools in the Czech-German linguistically mixed territories underwent somewhat peculiar development during twenty years of the existence of the First Republic. The amendment of the controversial provisions concerning the establishment of schools from the Austro-Hungarian period led, on the one hand, to the "boom" of Czech educational institutions. On the other hand, MENE failed to respond to the problems associated with this "boom". The initial euphoria of the possibility to establish Czech schools for almost every Czech pupil was soon replaced by endless day-to-day disputes between the Czech and German population, which perceived this situation as an attempt to oppress their culture (Umlauf, 1960).

Despite the fact that in those twenty years, 14 times more Czech schools were set up in the political district of Ústí nad Labem than in the previous period due to unresolved relations with the German population, and these schools tragically ended in the occupation of the border areas by the Nazi forces in October 1938. In the following years, these schools entirely served the needs of the Nazi Third Reich, and of course, the Czech language was not used for teaching.

The existence of these schools, however, was not forgotten during the war. One of the other possible features of the sustainability of education becomes apparent here. These pioneer schools, as shown by Kučerová's research (2012), became the starting point for the renewal of Czech education after 1945, after the Second World War. After the German community was moved from Czechoslovakia, the border areas were inhabited by the Czech population from the upcountry, and the Czech schools were restored first. Simply put, they became the basis for the further development of primary education in this area.

The second point of view on the sustainability of education in the context of this study lies in the activities of Czech minority schools, namely the transfer of values of 
education or awareness of social and cultural values and other knowledge and skills necessary for functioning and responsible citizenship and active life as Guseva, Dombrovskis, and Iliško (2007) wrote. Although the occupation violently disrupted the development of these schools, it could have been expected that these schools had educated many children who, as adults, were active in the years after the Second World War.

It can be assumed that they were the bearers of the ideas of the democratic and republican establishment of the first Czechoslovak Republic as their spoken values were incompatible with the new communist system and ideas of Marxism-Leninism during the 1948 to 1989 . In a nutshell, they were tabooed, publicly could not be presented with impunity (see, for example, Zounek, Šimáně, \& Knotová, 2017; Zounek, Šimáně, \& Knotová, 2018). Although this issue has not been researched yet and, therefore, still represents a call for further research, it can be argued that in the case of the Prague Spring (1968) or even the Velvet Revolution (1989), this generation of Czech minority schools could have contributed to the revival of values, traditions and in general ideas of the first Czechoslovak Republic. At the same time, it could also follow up its legacy and therefore contribute not only to further development, but also to maintaining Czech education in the present Czech Republic.

Note:

(1) Among others, Jindrich Metelka, the Vice-president of the national school council and the author of the so-called Metelka Act, according to which the minority schools were established in the period of the first Czechoslovak Republic, was present at the meeting (for more details see the text of the Act Číslo 189, 1919).

(2) In the period of the first Czechoslovak Republic inhabited predominantly by the Germanspeaking population.

(3) The research data presented in this text was collected within the research for the author's dissertation thesis.

(4) Political district Ústí nad Labem was established based on the Realm Act from 1868 (Verordnung des Ministers, 1869). According to the law, this political district included judicial districts of Ústí nad Labem and Chabařovice. This administrative division was valid until 1938 when the districts became part of the Nazi German Empire. The town Ústí nad Labem is currently part of the Ústí region located in the north of the Czech Republic.

(5) Political district Ústí nad Labem was predominantly inhabited by German population. For example, in 1921 in the town of Ústí nad Labem the German people reached 80\% of the whole population, as well as in 1930. The German population prevailed in all the municipalities of the district except for one. This was village Roudníky, where, due to the ethnic distribution of population, even the German primary minority school was established (for more see Šimáně, \& Zounek, 2012).

(6) In the former Austro-Hungarian Empire, German (or Hungarian) language and culture were favoured at the expense of other nations of this former multinational empire.

(7) Paradoxically, this was also true for the inhabitants of Carpathian Ruthenia, where autonomy was formally introduced by the Czechoslovak Constitution of 1920, but which did not actually start to apply until November 1938 (for more see Hořec, 1994).

(8) These were closed territories in foreign-language areas and some larger cities with a significant proportion of the German population. Examples of such places are Jihlava, Olomouc, Vyškov, Brno, České Budějovice, etc. (see Besch, 1992). 
(9) The term Sudeten German or the phrase Sudeten Germans is a term describing members of the German population living in the territory of the Czechoslovak Republic. For this population, formerly referred to as Deutschböhme, Deutschmährer, Deutschschlesier (according to the region concerned), this term established during the 1920s. For the first time it is said Franz Jesser used it in his Deutscher Volksgebot newspaper article in 1902 as a reference to all the three groups of Germans that was missing (see, for example, Pernes, 2005; Valenta, 1998).

(10) In March 1933 the Czechoslovak production reached only 56\% of the 1929 industrial production. The number of unemployed reached approximately seven hundred thousand (see Kárník, 2002).

(11) Konrad Henlein, founder and chief representative of the radical pro-Nazi political party of the First Republic of Czechoslovakia, called Sudetendeutsche Partei (SdP).

(12) The program of the SdP requirements to the Czechoslovak Government of 24 April 1938. The program contained eight points and was based on Henlein's meeting with Adolf Hitler. It represented the fulfilment of the Czech Germans' efforts to divide the Czech lands into the Czech and German parts.

(13) These problems did not concern Czech schools established in the Austro-Hungarian period. In these cases, these schools mostly owned their school building because they were under the patronage of one of the Czech school associations. For example, schools in Krásné Březno and Chabařovice were built at the cost of the Central School Association (Ústřední matice školská) and North Bohemian National Unity (Národní jednota severočeská).

(14) For schools in the Ústí region the material has been preserved in a very high number and, with few exceptions, these materials are included in all the funds of the schools mentioned in this paper. It is not an exception that these funds contain this kind of archival sources for each class in all years of the school's existence (for example Katalog I. třídy, 1919/20; Katalog 1. třídy 1918/ 1919; Katalog 2. tř́ídy 1918/1919).

(15) Mainly entrance to the school on wooden stairs and a not enough light in the rooms.

\section{References}

Archival sources

Katalog 1. třídy 1918/1919 [Class 1 catalog 1918/1919]. Obecná škola v Krásném Březně [Primary school in Krásné Březno] (č. inv. 68, č. evid. 68, č. lok. 2798). Archiv města Ústí nad Labem, Ústí nad Labem.

Katalog 2. třídy 1918/1919 [Class 2 catalog 1918/1919]. Obecná škola v Krásném

Březně [Primary school in Krásné Březno] (č. inv. 69, č. evid. 69, č. lok. 2799). Archiv města Ústí nad Labem, Ústí nad Labem.

Katalog I. třídy, 1919/20 [Class I catalog 1919/20]. Obecná škola v Chabařovicích [Primary school in Chabařovice] (sg. OA/IV-18/12, poř. č. 638). Archiv města Ústí nad Labem, Ústí nad Labem.

Konferenční protokol 1934/1948 [Conference Protocol 1934/1948]. Česká státní škola v Ústí nad Labem - Předlicích [Czech state school in Ústí nad Labem - Předlice]. (č. inv. 24, č. evid. 24, č. lok. 2884). Archiv města Ústí nad Labem, Ústí nad Labem. Kronika školní [Chronicle of school]. Občanská škola v Chabařovicích [Civic School in Chabařovice] (sg. OA/IV - 17/1, kart. 612). Archiv města Ústí nad Labem, Ústí nad Labem.

Pojem "menšinová" škola [The term “minority” school]. Fond 371, Ministerstvo školství 1918-1949, I. díl, Pojem a rezoluce českých menšinových škol v ČSR [Ministry of 
Education 1918-1949, I. part, Concept and Resolutions of Czech Minority Schools in Czechoslovakia]. 1920-1934 (inv. č. 971, sg. 17Ma, č. kart. 373). Národní archiv, Praha.

Schulchronik 1919-1931 [School Chronicle 1919-1931]. Obecná a měšt'anská škola v Ústí nad Labem [Primary and civic school in Ústí nad Labem] (č. inv. 413, č. evid. 376, č. lok. 98. 1). Archiv města Ústí nad Labem, Ústí nad Labem.

Školní kronika 1919-1933 [School Chronicle 1919-1933]. 1 kniha. Obecná škola v Neštěmicích [1 book. Primary school in Neštěmice] (sg. OA/IV-26/7, kart. 1179). Archiv města Ústí nad Labem, Ústí nad Labem.

Školní kronika 1919-1939 [School Chronicle 1919-1933]. Obecná škola v Chabařovicích [Primary school in Chabařovice] (OA/IV - 16/1 kart. 612a). Archiv města Ústí nad Labem, Ústí nad Labem.

Školní kronika 1921/1935 [School Chronicle 1921/1935]. Obecná státní smíšená škola s vyučovacím jazykem československým v Ústí nad Labem, 1919-1938 [Primary state mixed school with czechoslovak teaching language in Ústí nad Labem, 1919_ 1938] (č. inv. 156). Archiv města Ústí nad Labem, Ústí nad Labem.

Školní kronika 1922-1938 [School Chronicle 1922-1938]. 1. kniha. Obecná škola v Chlumci [1. book. Primary school in Chlumec] (sg. OA/IV-20/1, kart. 796). Archiv města Ústí nad Labem, Ústí nad Labem.

Školy - různé záležitosti [Schools - various issues]. Registraturní plán I-III (I-XXII) (1900-1938). Okresní úřad Ústí nad Labem [Registry plan I-III (I-XXII) (19001938). District Office of Ústí nad Labem] (sg. VI/-, kart. 150). Archiv města Ústí nad Labem, Ústí nad Labem.

Školy - riozné záležitosti. Registraturní plán I-III (I-XXII) (1900-1938). Okresní úřad Ústí nad Labem [Schools - various issues]. Registraturní plán I-III (I-XXII) (1900_ 1938). Okresní úřad Ústí nad Labem [Registry plan I-III (I-XXII) (1900-1938). District Office of Ústí nad Labem] (sg. VI/-, kart. 151). Archiv města Ústí nad Labem, Ústí nad Labem.

\section{Legislation}

Číslo 189. Zákon ze dne 3. dubna 1919 o školách národních a soukromých ústavech vyučovacích a vychovávacích [Number 189. Law act from day $3^{\text {rd }}$ April 1919 about national schools and private educational institutions]. (1919). In Sbírka zákonů a nařizení státu československého [Collection of Laws and Regulations of the Czechoslovak State] (pp. 263-264). Praha: Státní tiskárna.

Číslo 295. Zákon ze dne 9. dubna 1920 o školách národních a soukromých ústavech vyučovacích a vychovávacích [Number 295. Law act from day $9^{\text {th }}$ April 1920 about national schools and private educational institutions]. (1920). In Sbírka zákonù a nařizení státu československébo [Collection of Laws and Regulations of the Czechoslovak State] (pp. 629-630). Praha: Státní tiskárna.

Č́íslo 53. Zákon, daný dne 2. května 1883, kterýmž se mění některá ustanovení zákona ze dne 14. května 1869 (Z. Ǩ , č. 62) [Number 53. Law act from $2^{\text {nd }}$ May 1883, which change some provisions of the law act from 14 ${ }^{\text {th }}$ May 1869 (I. C., n. 62)]. (1883). In Zákonník ř́íský pro království a země v radě říšské zastoupené [Imperial Code of Law for Kingdoms and Lands represented in the Imperial Council] (pp. 199_ 206). Vídeň: Císařské a královské tiskárny dvorské a státní.

Číslo 62. Zákon, daný dne 14. května 1869, jímžto se ustanovují pravidla vyučování ve školách obecných [Number 62. Law act from 14 $4^{\text {th }}$ May 1869, which is establishing 
the rules of teaching in primary schools]. (1869). In Přklad Zákonníka řišského vydaný pro království české [Translation of Imperial Code of Law for Czech Kingdom] (pp. 176-189). Praha: Místodržitelská tiskárna.

Verordnung des Ministers [Regulation of the Minister]. (1869). Access from http://alex.onb.ac.at/cgi-content/alex? aid=rgb\&datum=1868\&page=315\&size=45

Memoirs

Drtina, P. (1991). Československo můj osud [Czechoslovakia my destiny]. Praha: Melantrich.

Goldbach, W. (1998). Siertsch/Borschim: zwei böhmischer Dörfer: ihr Werden, ibre Kirche, ibre Schule, ibre Menschen, die Vertreibung ibrer deutschen Bewohner [Siertsch/Borschim: Two Czech Villages: their becoming, their church, their school, their people, the expulsion of their German inhabitants]. Ockenfels: Selbstverlag.

\section{Literature}

Badjanova, J., \& Iliško, Dz. (2015). Holistic approach as viewed by the basic school teachers in Latvia, Discourse and Communication for Sustainable Education, 6, 132-140.

Bakke, E. (2004). The Making of Czechoslovakism in The First Czechoslovak Republic. In Loyalitäten in der Tschechoslowakischen Republik 1918-1938. Politische, nationale und kulturelle Zugehörigkeiten [Loyalty in the Czechoslovak Republic 1918-1938. Political, national and cultural affiliations] (pp. 23-44). München: R. Oldenbourg Verlag.

Besch, W. (1992). Die deutsche Sprache in den Böhmischen Ländern [The German language in the Czech lands]. In H. Rothe (Ed.). Deutsche in der Böhmischen Ländern [Germans in the Czech lands] (pp. 83-102.). Köln: Böhlen.

Broklová, E. (1993). Nesamozřejmost demokracie [Not matter of course of democracy]. In Ztroskotání spolužití. Čěsi, Němci a Slováci v první republice 1918-1939 [Collapse of cohabitation. Czechs, Germans and Slovaks in the first republic of 19181939] (pp. 72-87). Praha: Ministerstvo zahraničních věcí České republiky.

Brügel, J. W. (2006). Čěsi a Němci 1918-1938 [Czechs and Germans 1918-1938]. Praha: Academia.

Deyl, Z. (1990). Z novějšího výzkumu státní činnosti v sociální oblasti 1918-1924 [Newer State social Aactivity research 1918-1924]. In Politický systém a státní politika v prunich letech existence Československé republiky 1918-1923 [Political System and State Policy in the First Years of the Czechoslovak Republic 19181923] (pp. 122-168). Praha: Historický ústav ČSAV.

Ferenčuhová, B. (2006). Ochrana národnostných menšín v Spoločnosti národov a československá politika (1919-1926) [Protection of national minorities in the league of nations and Czechoslovak Politics (1919-1926)]. In Hledání jistoty v bourlivých časech. Čěsi, Slováci, Němci a mezinárodní systém v pruní polovině 20. století [Seeking security in stormy times. Czechs, Slovaks, Germans and the international system in the first half of the $20^{\text {th }}$ century] (pp. 107-138). Ústí nad Labem: Albis international.

Glassl, H. (1995). Pokus multinárodního řešení. Bylo Československo vzornou demokracií? [Attempt of a multi-national solution. Was Czechoslovakia an exemplary democracy?] In Češi a Němci - historická tabu [Czechs and Germans - historical taboo] (pp. 127-132). Praha: Prago Media. 
Guseva, S., Dombrovskis, V., \& Iliško, Dz. (2007). Preparing children for school: the perspective of sustainability. Journal of Teacher Education for Sustainability, 8, 48-58.

Hanzal, J. (1999). Občan a stát - proměny myšlení [Citizen and State - Changes of Thought]. In Československo 1918-1938. Osudy demokracie ve střední Evropě [Czechoslovakia 1918-1938. The fates of democracy in Central Europe] (pp. 148151). Praha: Historický ústav AV ČR.

Harna, J. (1990). Politické strany a formování politického systému v Československu po roce 1918 [Political parties and formation of the political system in Czechoslovakia after 1918]. In Politický systém a státní politika v pruních letech existence Československé republiky 1918-1923 [Political System and State Policy in the First Years of the Czechoslovak Republic 1918-1923] (pp. 8-62). Praha: Historický ústav ČSAV.

Helus, Z. (2004). Dítě v osobnostním pojetí: obrat k dítěti jako výzva a úkol pro učitele $i$ rodiče [Child in personality: Turning to the child as a challenge and task for teachers and parents]. Praha: Portál.

Hoensch, J. K. (1969). Zum sudetendeutsch-tschechischen Verhältnis in der Ersten Republik [To the Sudeten German-Czech relationship in the First Republic]. In E. Lemberg, \& G. Rhode (Eds.). Das deutsch-tschechische Verhältnis seit 19181969 [The German-Czech relationship since 1918-1969] (pp. 21-48). Stuttgard: W. Kohlhammer Verlag.

Hořec, J. (1994). Z dějin Podkarpatské Rusi [From the history of Subcarpathian Russia]. Praha: Česká expedice.

Iliško, Dz. (2007). Teachers as agents of societal change. Journal of Teacher Education for Sustainability, 7, 14-26.

Iliško, Dz., et al. (2017). Meeting the challenges of ESD competency - based curriculum in a vocational school setting. Discourse and Communication for Sustainable Education, 8(2), 103-113.

Jaworski, R. (1991). The German Minorities in Poland and Czechoslovakia in the Interwar Period. In P. Smith (Ed.). Ethnic Groups in International Relations. Comparative Studies on Goverments and non-dominant Ethnic Groups in Europe 1850-1940 (pp. 169-185). New York: University Press.

Kaiser, V. (1995). Komunální politika města Ústí nad Labem [Municipal Policy of the City of Ústí nad Labem]. In Dějiny města Ústí nad Labem [History of city of Ústí nad Labem] (pp. 166-188). Ústí nad Labem: Albis International.

Kárník, Z. (1999). Ustanovení ČSR jako parlamentní demokracie v podmínkách národněpolitické a sociálněpolitické krize střední Evropy (jaro-léto 1920) [Provisions of Czechoslovakia as Parliamentary Democracy in the Context of the National Political and Social-Political Crisis of Central Europe (Spring-Summer 1920)]. In Československo 1918-1938. Osudy demokracie ve střední Evropě [Czechoslovakia 19181938. The fates of democracy in Central Europe] (pp. 90-111). Praha, Historický ústav AV ČR.

Kárník. Z. (2002). České země v ére pruní republiky (1918-1938). Díl drubý. Československo a české země v krizi a obrožení (1930-1935) [Czech lands in the era of the First Republic (1918-1938). Part two. Czechoslovakia and the Czech Lands in Crisis and Threat (1930-1935)]. Praha: Libri. 
Kárník. Z. (2003). České země v ére pruní republiky (1918-1938). Díl první. Vznik, budování a zlatá léta republiky (1918-1929) [Czech lands in the era of the First Republic (1918-1938). Part One. The birth, construction and golden years of the republic (1918-1929)]. Praha: Libri.

Kořalka, J. (1997). Minderheitenstatus als Notausweg. Grundrätze der Rechtslage und des Minderheitenschutzes in den böhmischen Ländern vor 1914 und in Tschechoslowakischen Republik nach 1918 [Minority status as an emergency stop. Principles of the legal situation and the protection of minorities in the Bohemian lands before 1914 and in the Czechoslovak Republic after 1918]. In Die Minderheiten zwischen den beiden Weltkriegen [The minorities between the two world wars] (pp. 96115). Berlin, Duncker u. Humblot.

Kořalka, J. (1998). Menšinový status jako východisko z nouze [Minority status as a last resort]. In Stereotypy a symboly [Stereotypes and symbols] (pp. 111-133). Praha: Institut základi̊ vzdělanosti UK.

Kováč, D. (1993). Česi, Nemci a Slováci v medzivojnovom Československu. Otázky a odpovede [Czechs, Germans and Slovaks in the interwar Czechoslovakia. Questions and answers]. In Ztroskotání spolužití. Češi, Němci a Slováci v pruní republice 1918-1939 [Collapse of cohabitation. Czechs, Germans and Slovaks in the first republic of 1918-1939] (pp. 255-266). Praha: Ministerstvo zahraničních věcí České republiky.

Kučerová, S. (2012). Proměny územní struktury základního školstvív Česku [Changes in the Territorial Structure of Primary Education in the Czech Republic]. Praha: Česká geografická společnost.

Kural, V. (1993). Československo jako národní stát? Sudetoněmecký problém [Czechoslovakia as a national state? Sudeten German problém]. In Ztroskotání spolužití. Češi, Němci a Slováci v pruní republice 1918-1939 [Collapse of cohabitation. Czechs, Germans and Slovaks in the first republic of 1918-1939] (pp. 88-99). Praha: Ministerstvo zahraničních věcí České republik.

Lemberg, H. (1993). Die Tschechoslowakei im Jahr 1. Der Staatsaufbau, die Liquidierung der Revolution und die Alternativen 1919 [Czechoslovakia in Year 1. The State Structure, The Liquidation of the Revolution and The Alternatives 1919]. In Das Jahr 1919 in der Tschechoslowakei und in Ostmitteleuropa [The year 1919 in Czechoslovakia and in East Central Europe] (pp. 225-248). München: R. Oldenbourg Verlag.

Lemberg, H. (2007). 1918: Die Staatsgründung der Tschechoslowakei und die Deutschen [1918: The founding of Czechoslovakia and the Germans]. In Wendepunkte in den Beziehungen zwischen Deutschen, Tschechen und Slowaken 1848-1989 [Turning points in relations between Germans, Czechs and Slovaks 1848-1989] (pp. 119135). Essen: Klartext.

Loužil, J. (1995). Národní identita, domov a vlast sudetských Němců [National Identity, Home and Land of Sudeten Germans]. In Češi a Němci - historická tabu [Czechs and Germans - historical taboo] (pp. 85-93). Praha: Prago Media.

Matějček, J. (2003). O německé menšině za první republiky jen trochu jinak [About the German minority in the First Republic just a little different]. In Z. Radvanovský (Ed.). Semper idem. Jiřimu Tưmovi k pětasedmdesátinám [Semper idem. To Jiří Tůma to the seventy-five] (pp. 68-76). Ústí nad Labem: Katedra historie Pedagogické fakulty Univerzity Jana Evangelisty Purkyně. 
Měchýř, J. (1996). České menšinové školství v Čechách 1867-1914 [Czech minority education in Bohemia 1867-1914]. In Sborník k problematice multietnicity: Češi, Němci a Židé ve společenském životě českých zemi 1848-1918 [Proceedings on Multiethnic Issues: Czechs, Germans and Jews in the Social Life of the Czech Lands 1848-1918] (pp. 67-84). Praha: Univerzita Karlova.

Měchýř, J. (1998). Vzory chování dělníka v Českých zemích v 19. století [Patterns of worker behavior in the Czech lands in the $19^{\text {th }}$ century]. Studie k sociálním dèjinám [Study on social history], 1(8), 99-119.

Pernes, J. (2005). Česko-německé soužití ve společném státě v 19. a 20. století [CzechGerman coexistence in a common state in the $19^{\text {th }}$ and $20^{\text {th }}$ centuries]. In Konec soužití Čechů a Němcuiv Československu. Sborník k 60. výročí ukončení 2. světové války [The end of the coexistence of Czechs and Germans in Czechoslovakia. Proceedings for the $60^{\text {th }}$ anniversary of the end of World War II] (pp. 23-31). Brno: Centrum demokracie a kultury.

Peroutka, F. (1991). Budování státu. Díl 1. 1918/1919 [Building the state. Part 1. 1918/ 1919]. Praha: Lidové noviny.

Rahi-Tamm, A., \& Saleniece, I. (2016). Re-educating Teachers: Ways and Consequences of Sovietisation in Estonia and Latvia (1940-1960) from the Biographical Perspective. Journal of Baltic Studies, 47(4), 451-472.

Salite, I., et al. (2016). Sustainability from the Transdisciplinary Perspective: An Action Research Strategy for Continuing Education Program Development. Journal of Teacher Education for Sustainability, 18(2), 135-152.

Schelle, K. (2006). Organizace Československého státu v meziválečném období (19181938) [Organization of the Czechoslovak State in the Interwar Period (1918-1938)]. Praha: Eurolex Bohemia.

Staněk, L. (1909). Národnostní poměry v okresu ústeckém [National circumstances in the district of Ústí nad Labem]. In Vývoj a život českých menšin. Díl II. [The Development and Life of Czech Minorities. Part II] (pp. 443-465). Most: Severočeské menšinové knihkupectví a nakladatelství D. J. Bukač.

Šafránek, J. (1918). Školy české. Obraz jejich vývoje a osudů. II. svazek. R. 1848-1913 [Czech schools. An image of their development and fate. II. volume. Y. 1848-1913]. Praha: Matice česká.

Šimáně, M. (2010). K problematice zřizování českých menšinových obecných škol na Ústecku v letech 1867-1918 [On the issue of the establishment of Czech minority primary schools in Ústecko in 1867-1918]. E-Pedagogium, 10(4), 83-92.

Šimáně, M., \& Zounek, J. (2012). Metelkův zákon a jeho uplatnění při zřízení německé obecné menšinové školy v Roudníkách v letech 1918-1938 [Metelka’s law and its application to the establishment of the German primary minority school in Roudníky in 1918-1938]. In Kvalita ve vzdělávání. XX. výroční konference České asociace pedagogickébo výzkumu Praha, 10.-12. zář́ 2012 [Quality in education. XX. Annual Conference of the Czech Educational Research Association, Prague, $10^{\text {th }}$ $12^{\text {th }}$ September 2012] (pp. 648-654). Praha: Pedagogická fakulta UK.

Tóth, A., Novotný, L., \& Stehlík, M. (2012). Národnostní menšiny v Československu 1918-1938: od státu národníbo ke státu národnostnímu? [National minorities in Czechoslovakia 1918-1938: from national to multinational state?]. Praha: Univerzita Karlova. 
Trapl, M. (2003). České menšinové školství v letech 1918-1938 [Czech Minority Education in 1918-1938]. In České národní aktivity v pohraničních oblastech pruní Československé republiky [Czech National Activities in the Borderlands of the First Czechoslovak Republic] (pp. 109-117). Olomouc: Filozofická fakulta Univerzity Palackého.

Umlauft, F. J. (1960). Geschichte der deutschen Stadt Aussig [History of the German city of Aussig]. Bayreuth: Hilfsverein Aussig.

Valenta, J. (1995). Rozchod Němců s Čechy v českých zemích v roce 1918 [Breakup of Germans with Czechs in 1918]. In Češi a Němci - historická tabu [Czechs and Germans - historical taboo] (pp. 54-61). Praha: Prago Media.

Valenta, J. (1998). Léta 1918-1919: sebeurčení pro Čechy, Slováky a ...? [Years 19181919: self-determination for Czechs, Slovaks and ...?] In T. G. Masaryk a situacev Čechách a na Moravě od konce 19. století do německé okupace Československa [T. Masaryk and the situation in Bohemia and Moravia from the end of the $19^{\text {th }}$ century to the German occupation of Czechoslovakia] (pp. 69-80). Praha, Ústav T. G. Masaryka.

Valenta, J. (1999). Čtyři nástupnické státy a osudy jejich demokracie [Four successor states and the fates of their democracy]. In Československo 1918-1938. Osudy demokracie ve středni Evropě [Czechoslovakia 1918-1938. The fates of democracy in Central Europe] (pp. 223-231) Praha: Historický ústav AV ČR.

Wils, L. (1993). A historical Perspective. In Ethnic Groups and Language Rights (s. 291301). New York: NY University Press.

Zounek, J., \& Šimáně, M. (2014). Úvod do studia dějin pedagogiky a školství: kapitoly $z$ metodologie historicko-pedagogického výzkumu [Introduction to the Study of History of Education and Schooling. Chapters from the Methodology of Historical Research]. Brno: Masaryk University.

Zounek, J., Šimáně, M., \& Knotová, D. (2017). Normální život v nenormální době. Základní školy a jejich učitelé (nejen) v období normalizace [Normal Life in not so Normal Times. Primary Schools and Their Teachers (not only) During the Socalled Normalization Period]. Prague: Wolters Kluwer.

Zounek, J., Šimáně, M., \& Knotová, D. (2018). “You Have Betrayed Us for a Little Dirty Money!” The Prague Spring as Seen by Primary School Teachers. Paedagogica Historica International Journal of the History of Education, 54(3), 320-337.

Correspondence concerning this article should be addresses to Mgr. et Mgr. Michal Šimáně, Ph.D., Mendel University in Brno, Institute of Lifelong Learning, Department of Social Sciences, Zemědělská 1/1665, Brno 613 00, Czech Republic. Email: simane@mendelu.cz 